\title{
Analysis and critical evaluation of structural features in four Cymbellaceae taxa from New Caledonia
}

\author{
René Le Cohu ${ }^{1}$, Horst LANGe-Bertalot ${ }^{2}$, Bart VAN De VIVER ${ }^{3,4} \&$ Loïc Tudesque ${ }^{5}$
}

${ }^{1}$ ECOLAB, Université de Toulouse, CNRS, INP, UPS, Toulouse, France

${ }^{2}$ University of Frankfurt \& Senckenberg Museum, Seckenberganlage 31-33, 60054 Frankfurt am Main, Germany

${ }_{3}^{3}$ Jardin botanique de Meise, Département de Recherche, Nieuwelaan 38, B-1860 Meise, Belgique

${ }^{4}$ Université d'Anvers, Département de Biologie-ECOBE, Universiteitsplein, B-2610 Wilrijk, Belgique

${ }^{5}$ Laboratoire Évolution \& Diversité Biologique (EDB UMR 5174), Université de Toulouse Midi-Pyrénées, CNRS, IRD, UPS. 118 route de Narbonne, Bat 4R1, 31062 Toulouse cedex 9, France

\begin{abstract}
Delicatophycus costei (Lange-Bertalot et Moser) Wynne, Cymbella bourrellyi Maillard, Cymbella latarea Maillard and Cymbella pernodensis Maillard are endemic to New Caledonia and show uncommon morphological features compared to the "sensu stricto" definition of their respective genus. Delicatophycus costei was described based on light microscopy and scanning electron microscopy (SEM) observations, confirming the generic LM diagnosis. However, the external view in SEM is atypical as both valve face and mantle are covered by longitudinal ribs, overlaying part of the zig-zag striae, generally accepted as the determinant generic feature. The three species of Cymbella have both apical pore fields and "stigmata". However, they show some specific morphological features compared to the more classically shaped Cymbella species. Cymbella bourrellyi has a narrow hyaline area on the valve face and the areolae are bordered internally by small outgrowths. Cymbella pernodensis is distinguished by internal biseriate striae. The internal morphology of Cymbella latarea is characteristic in having typical biseriate striae and bisected apical pore fields. In these three species, internally, the stigmata are continuous with the striae and appear as simple and only weakly separated structures at the end of the striae. The three species are also characterized by differences in the number of areola rows per stria externally and internally.
\end{abstract}

Key words : Cymbella, Delicatophycus, New Caledonia, taxonomy, ultrastructure

\section{INTRODUCTION}

The diatom flora of New Caledonia has been the subject of intensive taxonomic studies (MANGUIN 1962; MAILlard 1978; Le CoHU 1983, 1985; Moser et al. 1995, 1998; Moser 1999; Watanabe \& Asai 2008; Marquie et al. 2018; Le CoHU et al. 2018, 2019). New Caledonia is very famous for its unparalleled plant endemism, partly due to its ultramafic soils which are known to be nickelcobalt rich (JAFFrE et al. 2009; MoraT et al. 2012). The same observation applies to its freshwater diatom flora. According to Moser (1999) about 40\% of the diatom taxa is considered to be endemic. MANGUIN (1962) and MAILlARD (1978) included all biraphid taxa showing a dorsiventral symmetry within the genus Cymbella. In the past 20 years however, the genus has been split into several new or resurrected genera (KRAMMER 1997a,b, 2002, 2003; JÜTTNER et al. 2010; KULIKOVSKIY et al. 2012; BAHLs 2015; KulikovSKIY \& KuZNETSOVA 2016; Kaspustin et al. 2017). Recently, Wynne (2018) found out that one of the newly described genera, Delicata Krammer, was invalidly described and replaced it by the genus Delicatophycus Wynne. Several of the species described by MANGUIN (1962) and MAILLARD (1978) have been transferred to the genera Encyonema, Encyonopsis, Delicata, Cymbopleura and Cymbellopsis (KRAMMER 1997a, b, 2003; Moser et al. 1998; Moser 1999). In 2012 and 2013, a survey of the epilithic diatom flora in the running waters of New Caledonia was initiated to support water quality monitoring. Previous descriptions of the endemic species Delicatophycus costei (LangeBertalot \& Moser) Wynne, Cymbella bourrellyi Maillard, C. latarea Maillard and C. pernodensis Maillard were based solely on LM descriptions. Scanning electron microscopy observations provided in this paper added valuable morphological information on several structural features of the genera Delicatophycus and Cymbella.

In this paper, we provide detailed morphological descriptions for the four endemic species cited above. Additionally, Cymbella novazeelandiana Krammer and 
C. tumida (Brébisson) Van Heurck, typical and classical representatives of the genus Cymbella s.s. are illustrated to highlight the morphological or structural features of the endemic species.

\section{Material ANd Methods}

Epilithic river diatoms were sampled in 79 sites across the main island of New Caledonia. The samples were brushed from pebbles, rocks and boulders and fixed in situ with 3-4\% of formaldehyde solution. For diatom analysis, small aliquots of the samples were oxidized using concentrated $\mathrm{H}_{2} \mathrm{O}_{2}$ and rinsed three times with demineralized water. The resulting cleaned diatoms were mounted in Naphrax. Light microscopy analysis was performed using an Olympus BX51 microscope equipped with differential interference contrast (Nomarski) optics and a SC30 digital camera. For SEM analysis, cleaned diatoms were dried onto coverslips attached to aluminum stubs using nail varnish. The stubs were sputter-coated with $5 \mathrm{~nm}$ of platinum (Leica EMMED 020, Vienna, Austria) and observed with a FEG FEI Quanta 250 (Eindhoven, Holland). Diatom terminology follows Ross et al. (1979), Round et al. (1990) and Krammer $(2002,2003)$.

\section{ObServations}

Delicatophycus costei (Maillard ex Lange-Bertalot et Moser in Moser et al.) Wynne (Figs 1-18)

Basionym: Cymbella costei Maillard (MaILlard 1978) nom inval. Synonyms: Cymbella delicatula var. costei (Maillard) Lange-Bertalot et Moser in Moser et al. (1995); Cymbopleura costei (Maillard) Krammer et Lange-Bertalot in Moser et al. (1998), Delicata costei Krammer et Lange-Bertalot (Krammer \& LANGE-Bertalot 2003).

\section{Description}

Light microscopy (Figs 1-10): Valves dorsiventral with narrowly rounded apices. Valve dimensions $(n=20)$ : valve length: $18-33 \mu \mathrm{m}$, valve width 4-6 $\mu \mathrm{m}$, length/width ratio: 4.8-6.5 (including new measurements). Central area marked by the presence of a few longer striae on the ventral side. Pseudostigmoids occasionally visible (Figs 6, 7), Raphe branches showing a steep inflexion towards the ventral side approaching the valve center, characteristic of the genus Delicatophycus. Striae parallel at the center of the valve, becoming slightly radiate towards the apices $(21-23$, rarely 25 in $10 \mu \mathrm{m})$.

Scanning electron microscopy (Figs 11-18): Axial area narrow. Central area asymmetrical, slightly ventrally enlarged (Figs. 11-12). External raphe branches lateral. Central raphe endings first deflected towards the primary valve side, finally slightly dorsally deflected (Fig. 13). Terminal raphe fissures dorsally deflected, bordered by a notch on the dorsal side (Figs 12, 14, arrows). Internally, raphe branches straight terminating onto small helictoglossae (Fig. 15), lacking an intermissio (Fig. 16). Externally, striae almost entirely obscured on both sides by strongly silicified ribs (Figs 11-14); when discernible, parts of the striae bordering the axial area more or less zig-zag shaped with areolae continuing without interruption onto the mantle (Figs 17-18). Internally, striae moniliform, uniseriate, composed of a series of open areolae (Fig. 16). Externally, two to four pseudostigmoids separated from the striae (Figs 12, 13, 18, arrowheads) at the center; internally pseudostigmoids appearing as simple longer areolae located at the end of the proximal striae (Fig. 16, arrowheads).

Remarks: The taxonomic position of this species within the genus Delicatophycus is confirmed based on a combination of the partly zig-zag shaped striae, the lateral structure of the raphe, the presence of the pseudosigmoids and the absence of apical porefields, all typical features of the genus (Krammer 2003). However, based on the new observations, several features such as minimal length, width, stria density and length/width ratio should be amended in the original description: valve length: 18 (not 23)-33 $\mu \mathrm{m}$, width 4 (not 4.5)-6 $\mu \mathrm{m}$, length/width ratio 4.8 (not 5.3)-6.5 and 21-23 (exceptionally 25) striae in $10 \mu \mathrm{m}$.

Ecology and Distribution: It should be noted that among 29 species of Delicatophycus, 6 are endemic to New Caledonia (Guiry \& Guiry 2019; Le CoHU et al. 2018, 2019). Delicatophycus costei is found in several rivers: Baie Nord - Bras sud, Nomac, rivière des lacs, Wa Menao, Nekliai (type locality), Oumbaye where $D$. costei is frequent (J. MARQUIÉ pers. com.).

Cymbella bourrellyi Maillard ex Lange-Bertalot et Moser in Moser et al. (Figs 19-29)

\section{Description}

Light microscopy (Figs 19-23): Valves slightly dorsiventral with broadly rounded, not-protracted apices. Valve dimensions ( $n=25)$ : valve length $82-172 \mu \mathrm{m}(130-200$ $\mu \mathrm{m}$ according to MAILLARD, 1978), valve width 13.5-20 $\mu \mathrm{m}(18-28 \mu \mathrm{m}$ according to MAILLARD, 1978). Axial area relatively broad, about $1 / 4$ of the total width, widening towards the valve center to form a slightly asymmetrical (at the ventral side) central area. Raphe lateral in most of its course, filiform near the central and terminal ends. Terminal raphe fissures dorsally deflected (Fig. 22). Striae weakly radiate, $8-10$ in $10 \mu \mathrm{m}$, distinctly punctate, occasionally interrupted by discontinuous hyaline zones on the ventral and dorsal sides (Figs 20, 23, arrows).

Scanning Electron Microscopy (Figs 24-29): External central raphe endings expanded (Fig 25). Terminal raphe fissures dorsally deflected, bordered by a notch on the dorsal side (Fig. 26, arrowhead) and terminating at the valve face/mantle junction (Fig. 26). Internally, raphe branches straight terminating onto dorsally oriented helictoglossae. Central raphe endings separated by well-develop intermissio (Figs 27-29). Externally, striae uniseriate, composed of transapically elongated areolae (Figs 24-27), 8-10 areolae in $10 \mu \mathrm{m}$. Internally, striae composed of more or less elongated areolae situated in long shallow transapical grooves, irregularly bordered 

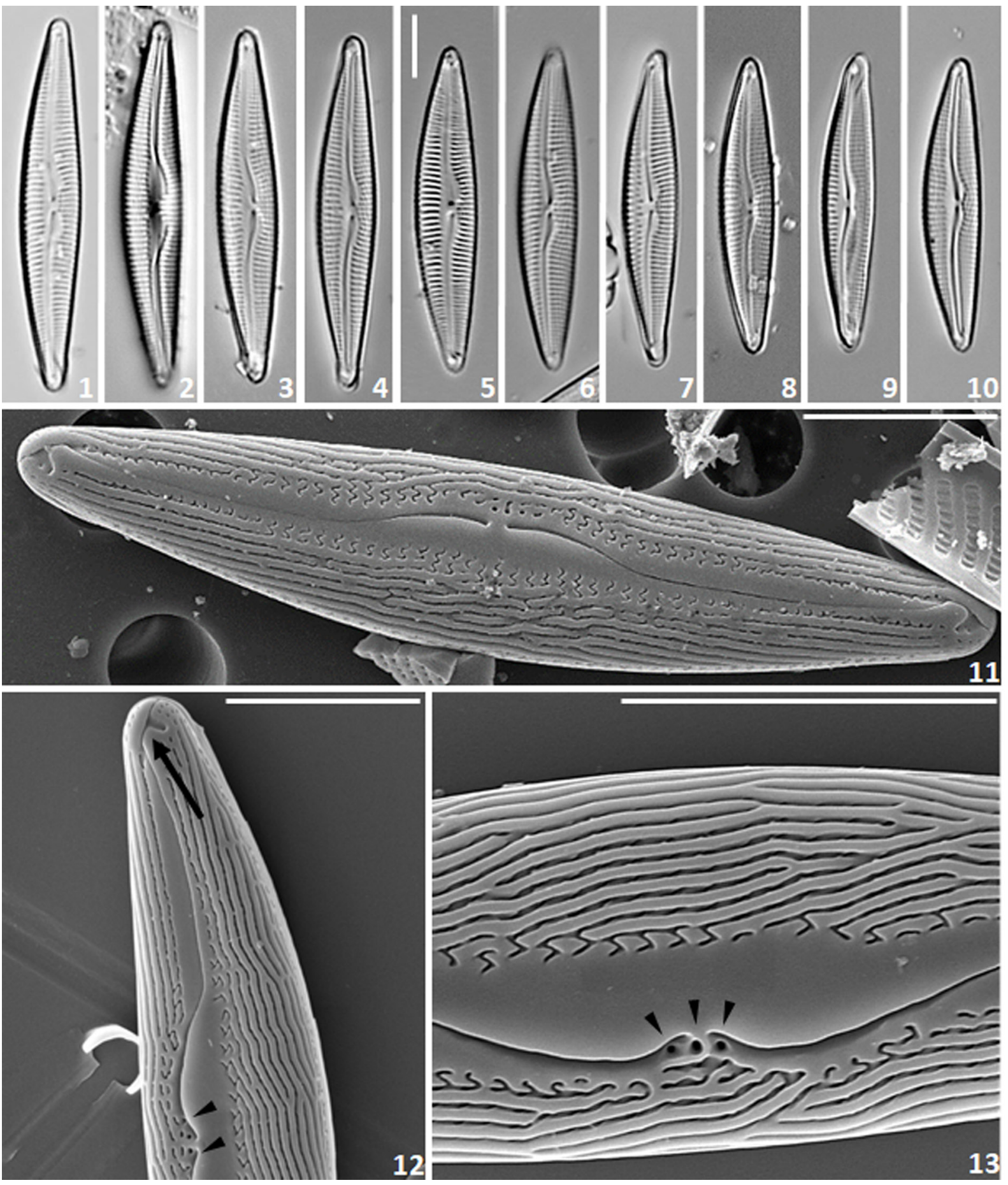

Figs 1-10. LM size range of the type population of Delicatophycus costei. Figs 11-13. Delicatophycus costei, SEM views: (11) external view of an entire valve; (12) fraction presenting pseudostigmoids (arrowheads) and notch on the dorsal side of the terminal fissure (arrow); (13) external view, close-up of the central area and pseudostigmoids (arrowheads). Scale bars $10 \mu \mathrm{m}(10), 5 \mu \mathrm{m}(11-13)$.

by a large number of small silica outgrowths which can delimit very small pseudospores (ca 35 in $10 \mu \mathrm{m}$; Figs $28,29)$. Striae interrupted by a very narrow hyaline area on both sides of the valve (Figs 24, 26-27, arrows). Large apical pore fields present at both apices, located on the valve mantle, barely continuing onto the valve face, never bisected by the terminal raphe endings (Figs $26,27)$. Externally stigmata on the ventral side, barely distinguishable from the areolae (Fig. 25, arrowheads) corresponding internally to a weak enlargement of the ends of the striae (Figs 28, 29, arrowheads) reminiscent of "structured stigma alveoli" (KRAMMER 2002).

Ecology and Distribution: Cymbella bourrellyi was only found in two rivers (river Dumbea and river Nekliai type locality). This species cohabits with Delicatophycus costei and C. latarea. 
Cymbella latarea Maillard (Figs 30-47)

Synonym: Encyonopsis latarea (Maillard) Krammer

\section{Description}

Light microscopy (Figs 30-37): Valves naviculoid, almost symmetric with respect to both the apical and transapical axes. Valve dimensions $(\mathrm{n}=20)$ : valve length $73-140 \mu \mathrm{m}$, valve width $12-17 \mu \mathrm{m}$. Axial area broad, almost $1 / 2$ of the total valve width, not or only slightly widening towards the central area. Central area only slightly broader on the dorsal side than the axial area. Central raphe endings deflected towards the primary valve side. Terminal raphe fissures clearly hooked (Fig. 30). Striae parallel in the valve middle becoming clearly radiate towards the valve apices, $12-14$ in $10 \mu \mathrm{m}$, distinctly punctate.

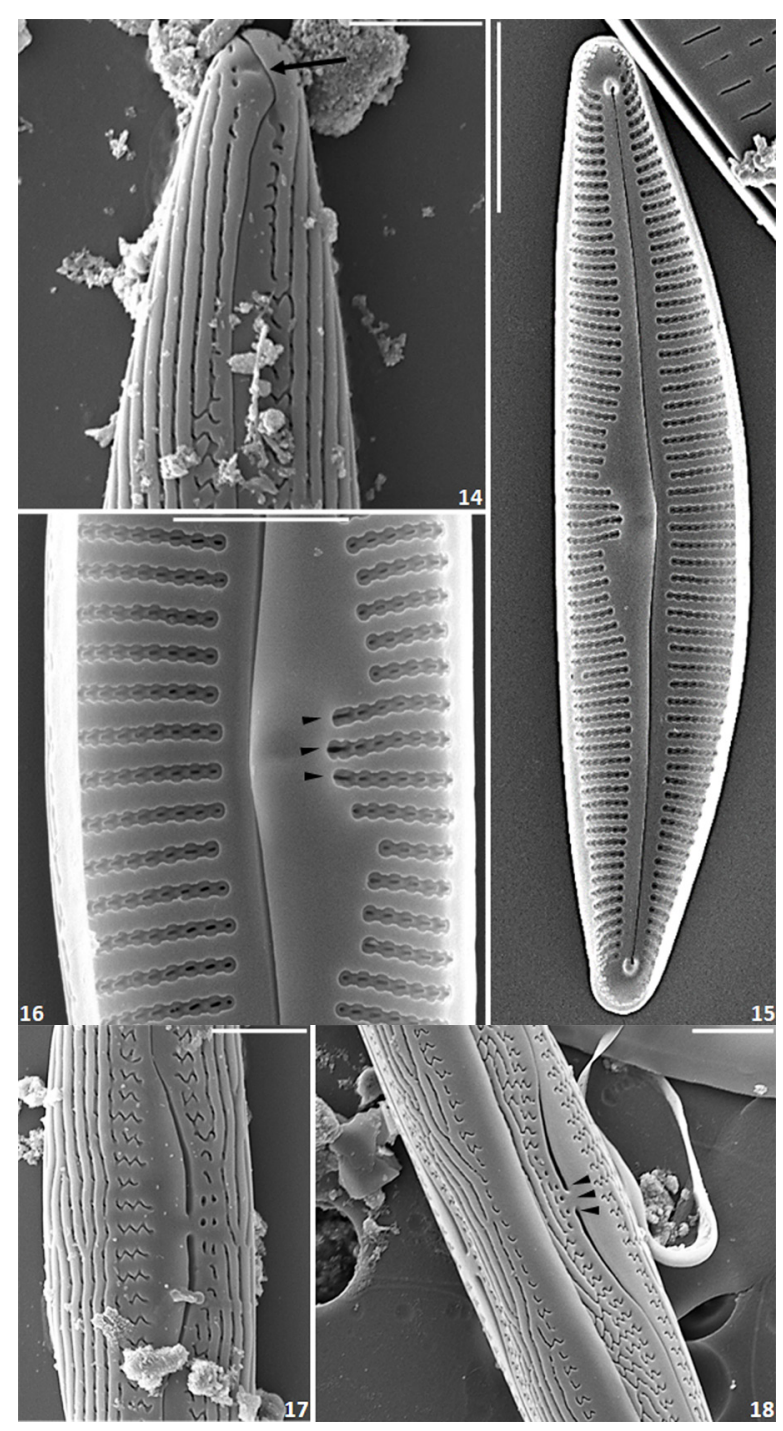

Figs 14-18. Delicatophycus costei, SEM views: (14) External view of a valve apex showing a notch on the dorsal side of the terminal fissure (arrowheads) and longitudinal ribs obscuring the striae; (15) Internal view of an entire valve; (16) Internal view of the valve center with pseudostigmoids (arrowheads); (17) External semi-lateral view showing longitudinal ribs on the mantle and twisted striae; (18) External view of two valves showing pseudostigmoids (arrowheads) and undulated striae. Scale bars $5 \mu \mathrm{m}$ (15), $2 \mu \mathrm{m}$ (14, 16-18).
Scanning electron microscopy (Figs 38-47): External central raphe endings expanded (Figs 38-40). Terminal raphe fissures dorsally hooked, continuing onto the mantle (Figs 41, 42), terminating near the mantle edge. Internally raphe branches straight (Fig. 43) terminating onto dorsally oriented helictoglossae (Figs 43, 44). Intermissio apparently lacking (Figs 45, 47). Externally, striae composed in the middle of the valve of irregularly shaped areolae (Figs 39, 40). In contrast, on the rest of the valve, areolae delicate, transapically elongated (Figs $38,41,42)$. Striae interrupted at the valve face/mantle junction by a clear hyaline zone, continuing afterwards onto the mantle (Figs 39, 41, 45). Areolae 10-14 in 10 $\mu \mathrm{m}$ externally. Internally, striae apparently biseriate, composed of two rows of small areolae, quincunxly arranged, bordered by short silica ingrowths (Figs 44, 45), 45-55 pairs of areolae in $10 \mu \mathrm{m}$. When eroded, striae uniseriate, composed of quadrangular areolae showing the vestiges of the ingrowths (Figs 47), 10-12 areolae in $10 \mu \mathrm{m}$. Apical pore fields composed of several rows of small pores, present on both apices, located almost entirely on the valve mantle, partly bisected by the terminal raphe (Figs 41, 42, 44, arrowhead). External stigma foramina, 4-7, often not clearly differentiated from the areolae (Fig 39, arrowheads), very variable in morphology (Fig. 40, arrowheads). Internally, stigmata appearing as a slight widening at the ends of the striae (Figs 45, 46, arrowheads). Cingulum composed of at least three open copulae (Fig. 41).

Ecology and Distribution: Cymbella latarea was recorded in about 12 rivers: Nekliai (type locality), Baie nord bras sud, Coco, Kaoris, Oumbaye, Duthio, Peoue, Karibouie, Talae nord, Talae sud, Dumbae and Kue. This taxon is frequent in the river Coco where its relative abundance can reach up to $17 \%$ (J. MARQuí́, com. pers.).

\section{Cymbella pernodensis Maillard ex Lange-Bertalot et Moser (Figs 48-62)}

Synonym: Cymbella pernodensis var. delicata Maillard nom. inval.

\section{Description}

Light microscopy (Figs 48-54): Valves hardly dorsiventral. Valve dimensions ( $\mathrm{n}=20)$ : valve length: $60-123 \mu \mathrm{m}$, width: $11-15 \mu \mathrm{m}$. Axial area relatively broad, almost 1/3 of the total valve width, very weakly widening towards the central area. Central area indistinct, only marked by the presence of stigmata on the ventral side. Raphe clearly lateral. Central raphe endings deflected to the ventral side. Terminal raphe fissures dorsally hooked. Striae almost parallel near the valve center, becoming gradually more radiate towards the apices, 9-11 in 10 $\mu \mathrm{m}$, clearly punctate.

Scanning electron microscopy (Figs 55-62): External central raphe endings expanded (Figs 55-57). Terminal raphe fissures dorsally weakly hooked, bordered by a notch on the dorsal side, terminating on the valve face, never continuing onto the mantle (Figs 58, 59). Internal 
raphe branches straight (Fig. 60) terminating onto small, dorsally oriented helictoglossae. Intermissio apparently lacking (Figs 61, 62). Externally striae composed of variable, irregularly shaped areolae, particularly in the middle of the valve, ranging from punctiform to transapically elongated and occasionally more or less vermicular (Figs 56-58). Internally, striae composed of double rows of small pores (Figs 60-62). Number of areolae different externally (uniseriate) and internally (biseriate), 10-13 (ext.) vs around 40 (int.) in $10 \mu \mathrm{m}$. Externally, apical pore fields composed of several parallel rows of small pores, located on both apices, almost exclusively on the valve mantle, not bisected by the terminal raphe endings. (Figs 58, 59). Internally, apical pore fields radially arranged around the helictoglossae (Fig. 61). Up to five stigmata present on the ventral valve side. External stigma foramina distinguished from the areolae in being often apically elongated (Fig. 62, arrowheads). Internally, stigmata appearing as a very slight widening of the ends of the striae. Cingulum composed of several open bands (Figs 58, 60). Valvocopula showing a fimbriate pars interior (Fig. 60).

Ecology and Distribution: C. pernodensis was found in 8 rivers: Creek Pernod (type locality, MaILlard 1978), Baie Nord Bras Sud, rivière des Lacs, Wa Menao, Boghen, Kaovis, Dothio and Mamie. Its relative abundance never exceeded 4\% (J. MARQUIÉ, pers. com.)

Cymbella novazeelandiana Krammer (Figs 63-68)

Light microscopy: see KRAMMER (2002, plate 51, figs 1-12)

Scanning electron microscopy (Figs 63-68): External
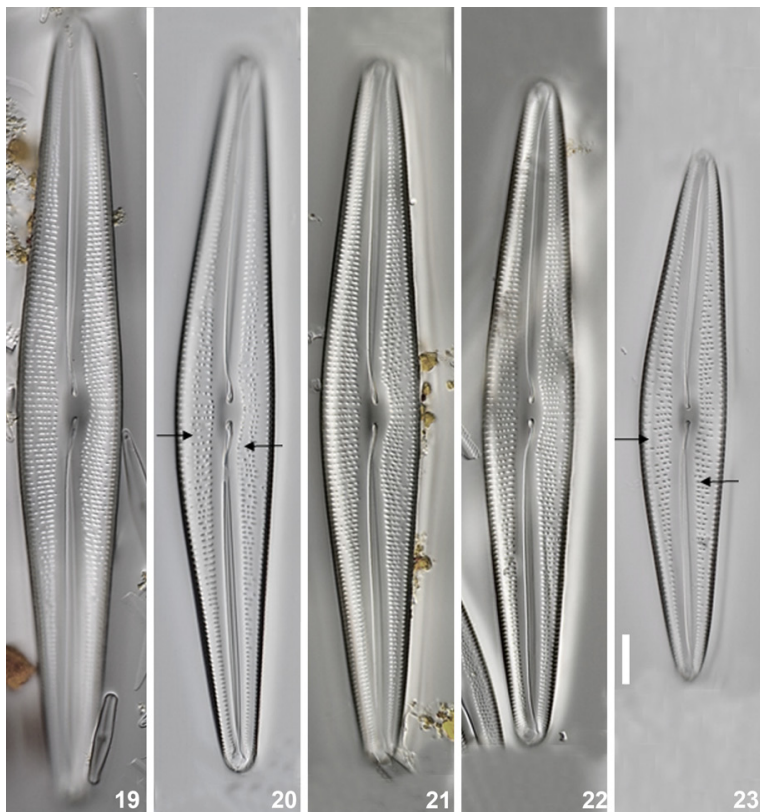

Figs 19-23. LM size range of the type population of Cymbella bourrellyi. Scale bar $10 \mu \mathrm{m}$. terminal raphe fissures abruptly bent towards the dorsal side, terminating onto the valve face (Figs 63-65). Striae composed of slit-like areolae, 10-11 in 10 $\mu \mathrm{m}$, extending onto the mantle (Fig. 64). Asymmetrical apical pore fields, composed of several parallel series of small pores, located at both apices, bordered by the terminal raphe fissures, extending slightly onto the valve face (Fig. 65). Internally, raphe fissures straight (Fig. 66) terminating onto small helictoglossae, the latter connected to the dorsal valve side by a very strongly silicified plate corresponding to the terminal fissure (Fig. 67). Intermissio indiscernible, probably obscured by the central nodule (Fig. 68). Apical pore fields internally showing clearly the parallel vertical series of pores (Fig. 67). External stigma foramina large, rounded, clearly separated from the central striae. Internally stigma openings having teeth-like ingrowths directly connected to the striae (Fig. 68).

Ecology and Distribution: Cymbella novazeelandiana was described from New Zealand where it is widely distributed, in oligotrophic waters (KRAMMER 2002) and should therefore not be considered endemic to New Caledonia, contrary to the three species discussed above. In New Caledonia, C. novazeelandiana was detected in 3 rivers (Pouembout, Boghen and Douenchour) but with a very low abundance $(<2 \%$, J. MARQuiÉ, pers. com.). The species is a typical example of the genus Cymbella with stigma alveoli, apical pore fields in the continuity of the striae and terminal raphe fissure dorsally deflected.

Cymbella tumida (Brébisson) Van Heurck (Figs 69-72) Light microscopy: see Krammer (2002, plates 162-164). Scanning electron microscopy (Figs 69-72): External central raphe endings clearly expanded. Terminal raphe fissures abruptly dorsally hooked (Figs. 69, 70). Striae composed of apically elongated areolae (Fig. 70). Central area more or less ovoid. One stigma on the ventral side clearly separated from the ventral striae (Fig. 70). Internally, apical pore fields radially arranged around the terminal nodule and anchored to the valve apex by a plate corresponding to the terminal fissure (Fig. 71). Raphe apparently lacking an intermissio (Fig. 72). Stigma elongated, clavate, located on the central nodule close to the raphe and structured by tiny pores (Fig. 72).

Ecology and Distribution: Cymbella tumida was described from Normandy (France); this species is distributed all over the world (cosmopolitan) and prefers oligotrophic to mesotrophic waters (KRAMMER 2002). In New Caledonia, C. tumida was detected in two rivers: Boghen and Gahoue.

Remarks: In the genus Cymbella, the morphology and the structure of the stigmata are very variable (KRAMMER 2002; JÜTTNER et al 2010b; Le COHU \& AzEMAR 2011; GRAEFF \& KocIOLEK 2013). The same observation can be made for both $C$. novazeelandiana and $C$. tumida. Compared to $C$. novazeelandiana, C. tumida has a 
different stigma type: it has a different position and it also differs by its structure from that of $C$. novazeelandiana.

\section{DISCUSSION}

Cymbella latarea and C. pernodensis as well as Delicatophycus costei and the other endemic Delicatophycus species on New Caledonia (LE CoHU et al. 2018, 2019) all show a common particularity: the presence of a notch on the dorsal side of the terminal raphe fissure. In the genus Encyonopsis, a more or less distinct bulge is observed at the end of the terminal raphe fissure (KRAMMER 1997b, pl. 147, fig. 3) but given its morphology and position on the terminal fissure, both features should be treated separately. The presence of this notch on the dorsal side of the terminal raphe fissure seems to be a specific feature of most of the New Caledonian endemic Cymbellales species, at least when the apical pore fields are not bisected by the raphe endings.

Delicatophycus costei can be differentiated from the other Delicatophycus species by two atypical Delicatophycus features: 1) the valve face and the mantle are almost entirely obscured by longitudinally running, strongly silicified ribs, unique within the genus Delicatophycus (Krammer 2003; Le CoHu \& Azemar 2011; LIU et al. 2018; Le CoHU et al. 2018) and 2) the central raphe endings are clearly oriented towards the dorsal valve side. Nevertheless, the species clearly belongs to the genus Delicatophycus. Parts of the striae in D. costei, close to the axial area, are discernible and show externally zig-zag shaped, continuous areolae, consistent with the areola structure typical for the genus Delicatophycus. The central raphe endings in Delicatophycus normally run parallel to the ventral and dorsal sides, with the exception of $D$. delicatula where the central endings are very weakly dorsally deflected (KRAMMER 2003), but the minor deflection in $D$. costei is not sufficient to remove D. costei from the genus Delicatophycu. Especially since the other diagnositic features for Delicatophycus such as dorsiventral valves, areola foramina showing an undulated pattern (at least in part of their course), the steep inflexion of the raphe branches towards the ventral side approaching the middle of the valve, the dorsally deflected terminal raphe fissures and the absence of apical pore fields, fit entirely with the genus description. The presence of longitudinal ribs on the valve face and mantle is an uncommon feature in diatoms and only found in a few diatom genera: Proschkinia (Round et al. 1990; MAJEWSKA et al. 2019), Navicula (SABBE et al. 2019), Haslea (SimONSEN 1974), Craticula (LANGEBertalot 2001), Pinnularia (Lange-Bertalot et al. 2003) and Navigiolum (LANGE-Bertalot et al. 2009). Two Stauroneis species, S. stodderi Greenleaf and $S$. staurolineata Reimer both possess very fine longitudinal ridges, running parallel from apex to apex (PATRICK \& ReImer 1966). In New Caledonia, Amphora dissimilis Metzeltin \& Krammer presents irregular longitudinal ridges (Moser et al. 1998, pl. 43, figs 1-6,) on its valve face. The species is however sufficiently different from $D$. costei to avoid confusion in light and scanning electron microscopy.

Cymbella novazeelandiana and C. tumida are two typical representatives of the genus Cymbella in New Caledonia. Both possess the predominant features of the genus such as apical pore fields on both apices, stigmata and dorsally deflected to hooked terminal raphe fissures. Cymbella bourrellyi, C. latarea and C. pernodensis

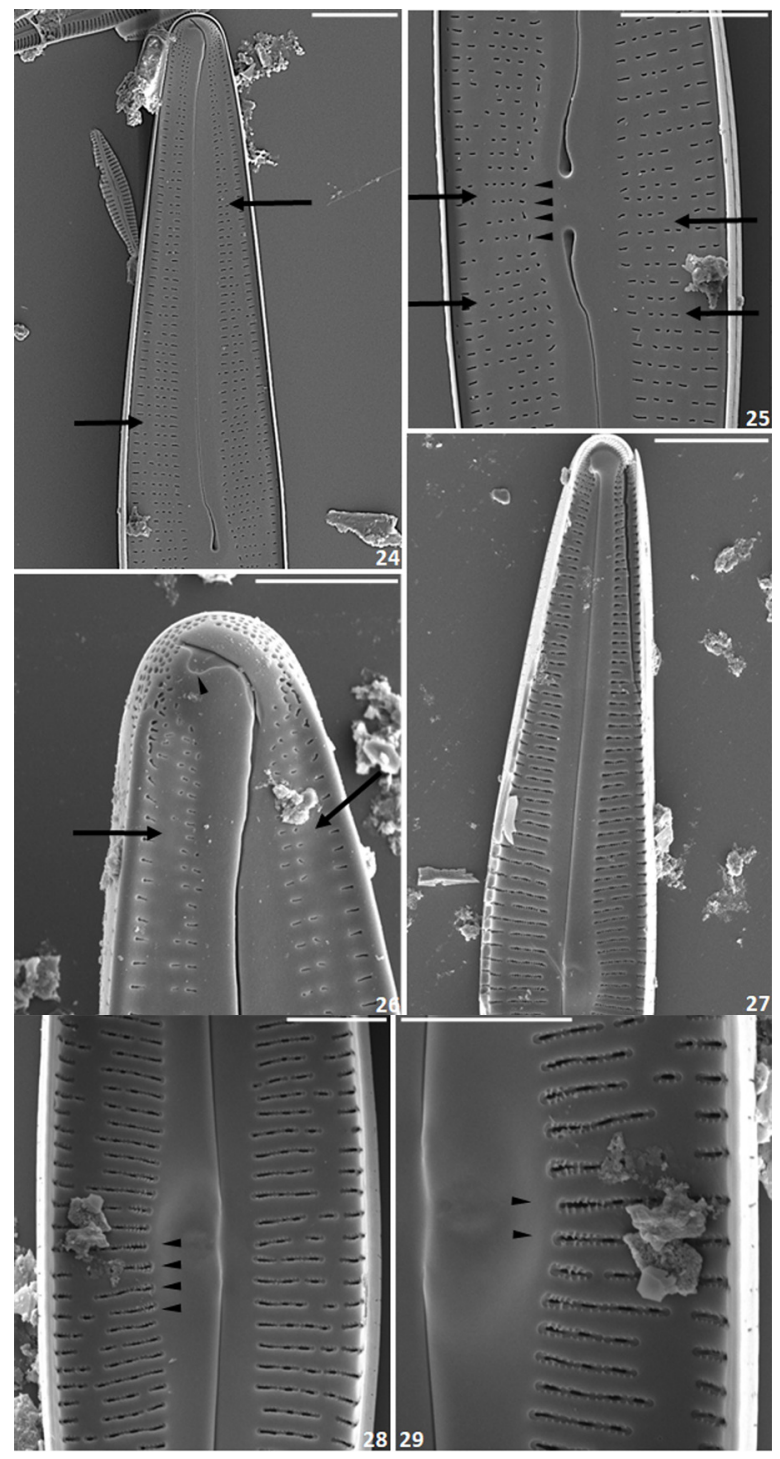

Figs 24-29. Cymbella bourrellyi, SEM views: (24) Half-valve external view showing the expanded proximal raphe endings and the longitudinal hyaline areas (arrows); (25) Detail of the external valve center with longitudinal hyaline areas (arrows) and pseudostigmoids (arrowheads); (26) External view of an apex showing longitudinal hyaline areas (arrows) terminal fissure with a notch on the dorsal side (arrowheads) and terminating at the junction valve face mantle; (27) Internal view of a valve fragment with longitudinal hyaline areas (arrows); (28) Detail of the inner valve center showing pseudostigmoids (arrowheads) and elongated areolae bordered by small outgrowths; (29) Detail of the central nodule showing pseudostigmoids and a long intermissio. Scale bars $10 \mu \mathrm{m}(24,25,27), 5 \mu \mathrm{m}(26,28,29)$. 
are native of New Caledonia. Their position within the genus Cymbella is mainly based on the presence and structure of the apical pore fields and the stigmata. But compared to the other Cymbella species, present in New Caledonia ( $C$. novazeelandiana and $C$. tumida), the three above mentioned species show several morphological characteristics that are unique within the genus:

1) The striae of most Cymbella species are uniseriate (figs 64, 66, 70, 72). Biseriate striae have been observed in C. diplopuncta Krammer (KRAMmer 2002) and at the apices of $C$. yaki Jüttner et Van de Vijver (JÜTTNER et al. 2010b). Recently, KASPUTIN et al. (2017) have described a new genus, Celebesia, based on two predominant features: the presence of biseriate striae, both on the external and the internal side, with alternately arranged areolae and undulating raphe branches. In C. latarea and C. pernodensis, the striae have only biseriate striae in the valve interior showing moreover a different structure compared to the biseriate striae in Celebesia. In the two Caledonian species, the areolae are split by prominent cross-bars whereas in Celebesia the areolae are located in shallow depressions.

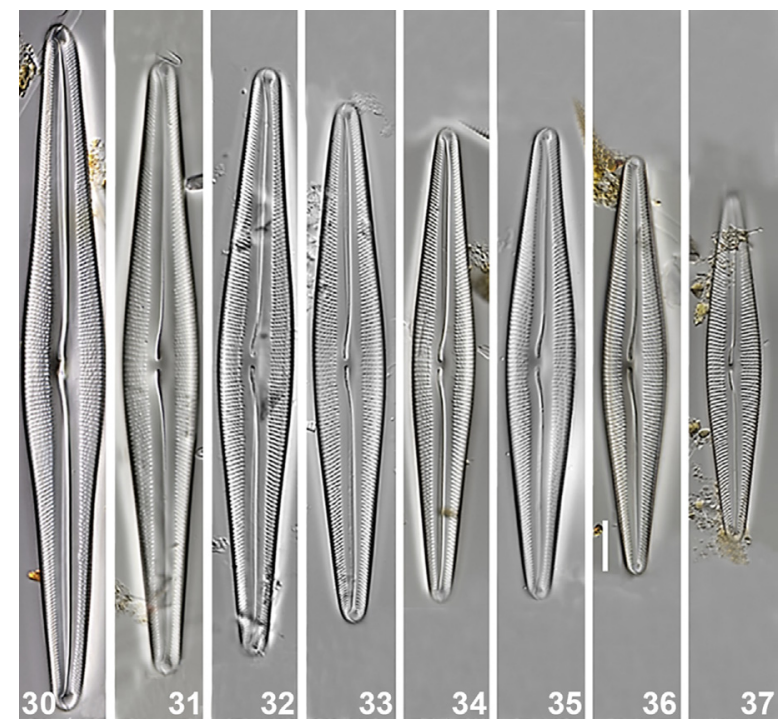

Figs 30-37. LM size range of the type population of Cymbella latarea Scale bar $10 \mu \mathrm{m}$.

Figs 38-47. Cymbella latarea, SEM views: (38) External view of a half-valve with transapically elongated areolae; (39) Detail of an external valve center showing pseudostigmoids, morphological variations of the areolae and the interruption of the striae at the margins; (40) Detail of another extended valve center showing arachnoid pseudostigmoids (arrowheads); (41) Detail of an external apex showing bisected apical pore fields, interruption of the striae at the valve margins and three open copulae (1, 2, 3); (42) External view of an apex showing the bisected apical pore field; (43) Internal half-valve; (44) Internal view showing the biseriate striae and the floor of the terminal fissure (arrowheads); (45) Internal center of a valve showing pseudostigmoids (arrowheads) and biseriate striae; (46) Detail of the striae structured by outgrowths and pseudostigmoids (arrowheads); (47) Striae eroded bordered by
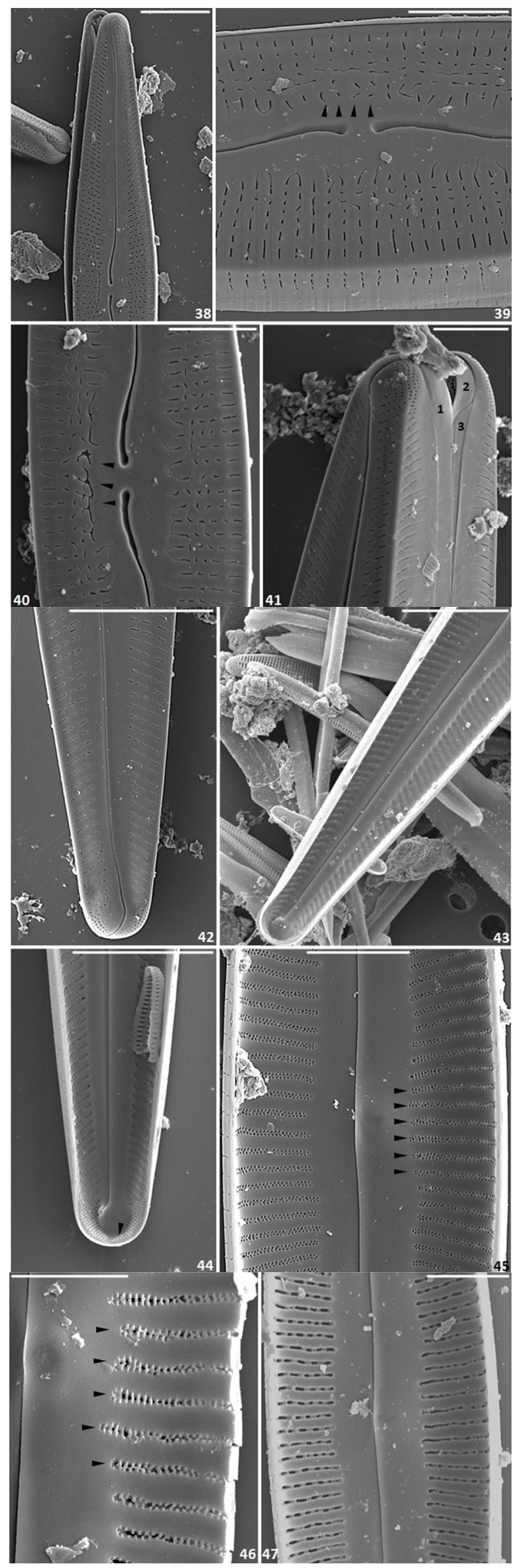

the remains of the outgrowths. Scale bars $10 \mu \mathrm{m}(38,42-44), 5 \mu \mathrm{m}$ (39-41, 45, 47), $3 \mu \mathrm{m}(46)$. 
2) In C. latarea and C. pernodensis, as in C. bourrellyi, the internal structure and the morphology of the striae does not reflect what is observed externally. Internally, the areolae are located in shallow grooves bordered by very small siliceous outgrowths, reminiscent of those in C. lancettula (Krammer) Krammer but in the latter, the outgrowths are reniform (KRAMMER 2002, pl. 25, fig. 10). The striae in C. bourrellyi show another particularity: the areolae are often irregularly spaced and the striae are interrupted on the valve face by a very narrow hyaline area on both sides of the valve, a feature never observed in any other Cymbella species.

3 ) In $C$. latarea and $C$. pernodensis, the external number of areolae and the internal number of areolae or pairs of pores differ completely different: $10-14$ vs $45-55$ in $10 \mu \mathrm{m}$ in $C$. latarea, $10-13$ vs 41 in $10 \mu \mathrm{m}$ in $C$. pernodensis. Usually, the number (in $10 \mu \mathrm{m}$ ) of external areolae matches the internal number, such as for instance $22-25$ in $10 \mu \mathrm{m}$ in C. novazeelandiana and ca. 15 in $10 \mu \mathrm{m}$ in C. tumida.

4) The morphology and the structure of the stigmata differs in $C$. bourrellyi, $C$. latarea and $C$. pernodensis compared to more typical Cymbella species such as C. novazeelandiana (figs 64, 68) or C. tumida (figs $70-72$ ). Usually, the stigmata are rounded externally (figs 64, 70) or clearly differentiated from the areolae (e.g. C. simonsenii Krammer (Krammer 2002, pl. 72, fig. 6; Le CoHU \& AzEmar 2011, fig. 47)). In the three endemic Cymbella species, the stigmata show a very variable morphology and are always not easy to separate from the areolae (figs 25, 39, 40, $56,57)$. Internally, in $C$. bourrellyi, C. latarea and C. pernodensis, the stigmata seem to form the final areola in the striae showing no difference in structure with the rest of the areolae. (figs 29, 45, 62). Species such as C. aspera (Ehrenberg) Peragallo (KRAMmer 2002, pl. 5, fig. 4), C. amelieana Van de Vijver et

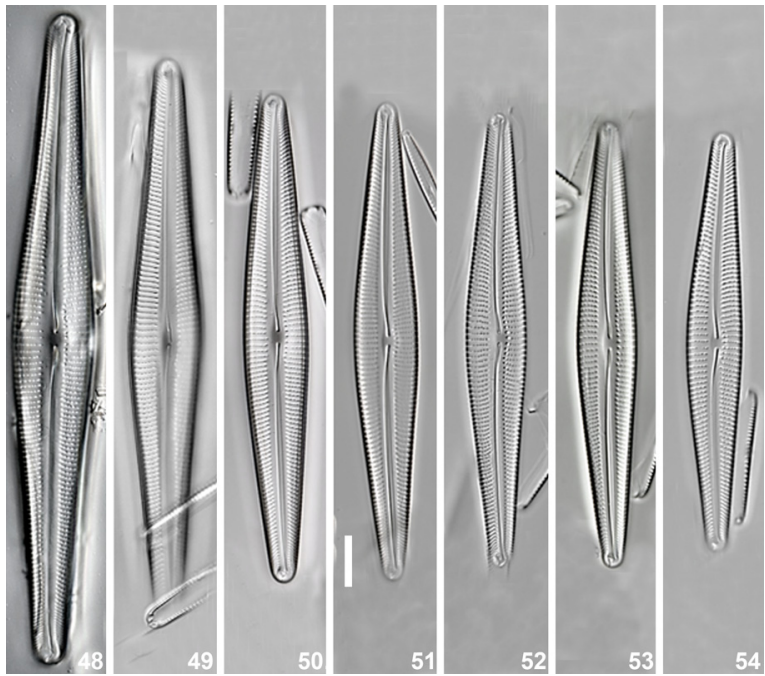

Figs 48-54. LM size range of the type population of Cymbella pernodensis. Scale bar $10 \mu \mathrm{m}$.
Lange-Bertalot (VAN DE VIJVER \& LANGE-BERTALOT 2008) or C. himalaspera Jüttner et Van de Vijver (JüTTNER et al. 2018b) lack specially formed internal stigma openings, but the stigmata seem to be clearly

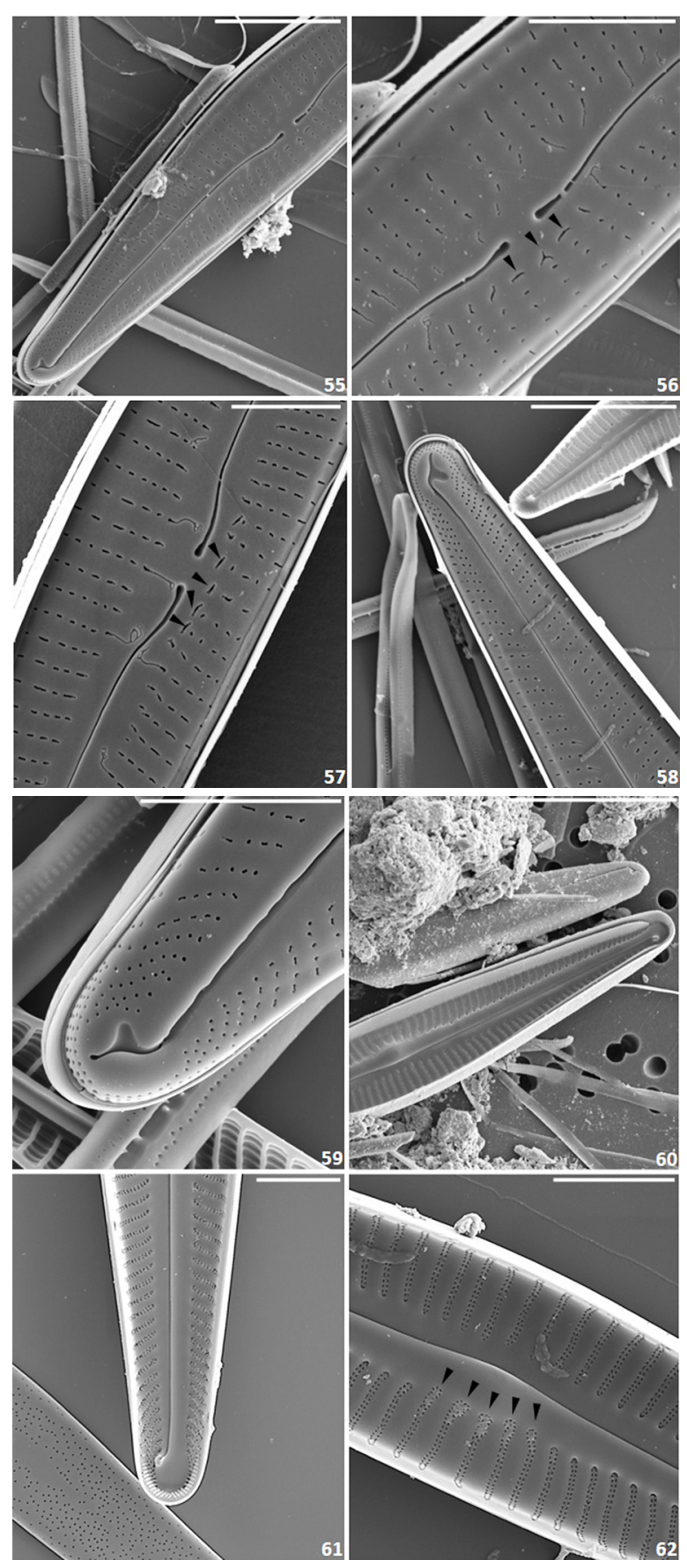

Figs 55-62. Cymbella pernodensis, SEM views: (55) External view of an half-valve; (56) Detail of an external valve center showing pseudostigmoids (arrowheads) and morphological variations of areolae; (57) Detail of another valve center showing pseudostigmoids and areolae sometimes vermicular; (58) External view of an apex, terminal fissure with a notch on the dorsal side and terminating at the junction valve face mantle, closed apex of a copula; (59) Detail of an apex, closed side of a valvocopula, apical pore fields and terminal fissures; (60) Internal view of a half-valve with open endings of a valvocopula; (61) Internal view of an apex showing striae biseriate and helictoglossae dorsally oriented; (62) Internal view of the valve center with biseriate striae and pseudostigmoids (arrowheads). Scale bars $20 \mu \mathrm{m}(60), 10 \mu \mathrm{m}(55,58), 5 \mu \mathrm{m}(56,57,59,61,62)$. 
differentiated from the striae.

5) Additionally, the orientation of the areolae seems to be different in $C$. bourrellyi, $C$. latarea and $C$. pernodensis. They are more or less transapically elongated whereas in the other Cymbella species most areolae are punctiform such as in $C$. designata Krammer (KRAMMER 2002, pl. 159, fig. 21), rounded as in C. helmckei Krammer (KRAMmer 2002, pl. 150, fig. 5), x-shaped as C. mexicana (Ehrenberg) Cleve (KRAMMER 2002, pl. 170, fig. 1) or most often apically slit-like as in C. novazeelandiana and C. tumida.

6) In most Cymbella species (KRAMMER 2002; JÜTTNER et al. 2010a,b; VAn DE ViJVer \& LANGE-Bertalot 2008; STANCHEVA \& Ivanov 2011; Rodianova et al. 2013), the apical pore fields are radially arranged around the terminal nodule. This was also observed

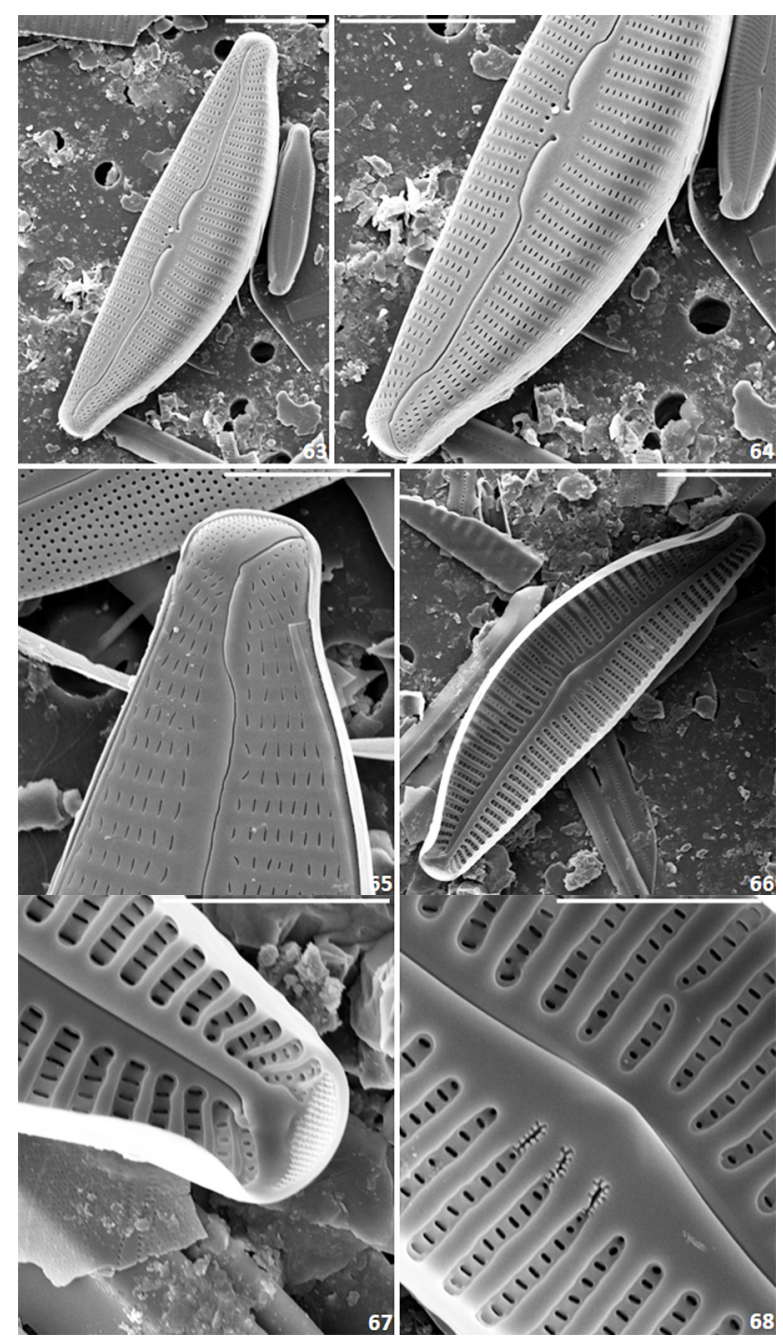

Figs 63-68. Cymbella novazeelandiana, SEM views: (63) External view of an entire valve; (64) External half-valve with stigmata and slit-like areolae; (65) Detail of an external view of an apex showing apical pore field separated from the striae by a hyaline area; (66) Internal view of an entire valve; (67) Detail of an apex in internal view, apical pore fields and nodule terminal anchored to the dorsal side by a plate corresponding to the floor of the terminal fissure; (68) Internal view of the center of the valve with "stigma alveoli". Scale bars $10 \mu \mathrm{m}(63,64,66), 5 \mu \mathrm{m}(65,67), 4 \mu \mathrm{m}(68)$. in C. bourrellyi, C. pernodensis, C. novazeelandiana and $C$. tumida. In C. latarea, however, the apical pore fields are bisected by the terminal raphe fissures (figs 41, 42, 44), a feature also observed in $C$. sinensis Metzeltin et Krammer and $C$. peraspera Krammer (Krammer 2002, pl. 121, fig. 7 and pl. 131, fig 6,). However, the latter two species have their apical pore fields only partially split into two parts by the terminal fissure. Moreover, the new genus Celebesia (KASPUTin et al. 2017) displays apical pore fields similar to those of $C$. latarea.

Two new genera have been more or less recently described, Oricymba (JüTTNER et al. 2010 a) and Celebesia (KASPUTIN et al. 2017). Both genera have features in common with Cymbella, such as the presence of apical pore fields, stigmata and dorsally deflected terminal raphe fissures. However, C. bourrellyi, C. latarea and C. pernodensis should not be transferred to any of these two genera. They can be differentiated from Oricymba by the absence of a marginal ridge, the structure of their areolae and by the apical pore fields in continuity with the striae whereas they are clearly separated from the striae in Oricymba. Cymbella bourrellyi, C. latarea and C. pernodensis are differentiated from all other Celebesia species by the structure and pattern of the striae and the raphe course, even if $C$. latarea shows bisected apical pore fields. It should be noted that the description of the

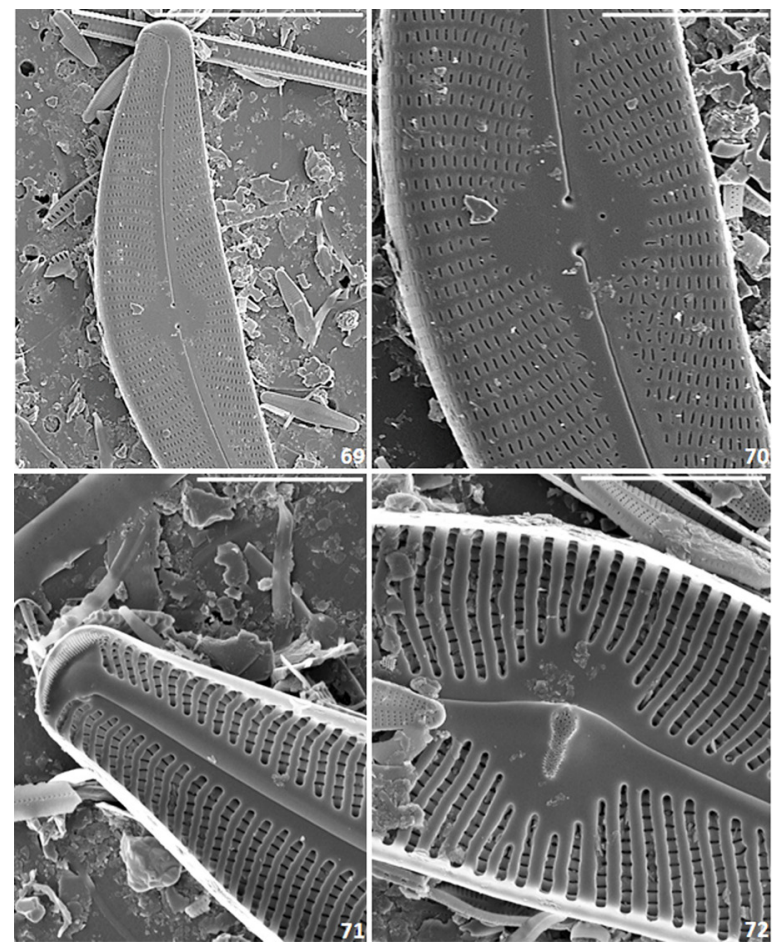

Figs 69-72. Cymbella tumida, SEM views: (69) External view; (70) Detail of the external valve center with stigma clearly separated from the striae; (71) Detail of an internal apex, apical pore field, helictoglossae anchored to the dorsal side by the floor of the terminal fissure; (72) Detail of an internal center with stigma on the terminal nodule and very close to the raphe. Scale bars $30 \mu \mathrm{m}$ (69), $10 \mu \mathrm{m}$ (70-72). 
new genus Celebesia was based on the stria structure and the raphe course although these two features have not been excluded from the diagnosis of Cymbella by KRAMMER (2002).

\section{ACKNOWLEDGMENTS}

This work has benefit from Association Nationale de la Recherche et de la Technologie (ANRT), the Observatory of the Environment in New Caledonia (OEIL) and Direction des Affaires Vétérinaires, Alimentaires et Rurales (DAVAR) grants. We are grateful to the CMEAB staff (Centre de Microscopie Électronique Appliquée à la Biologie) for their technical assistance and advice during SEM sessions.

\section{REFERENCES}

BAHLS, L.L. (2015): Kurkrammeria, a new genus of freshwater diatoms (Bacillariophyta, Cymbellaceae) separated from Encyonopsis. - Nova Hedwigia 101: 165-190.

GraefF, C.L. \& KocioleK, J.P. (2013): New and rare species of Cymbelloid diatoms (Bacillariophyceae) from Colorado (USA). - Nova Hedwigia 97: 87-116.

Jaffré, T.; Rigault, F.; Dagostini, G.; Tinel-Fambart, J.; WulfF, A. \& MunZINGER, J. (2009): Input of the different vegetation units to the richness and endemicity of the New Caledonian flora. - Flora 162: 54-59.

Jüttner, I.; Krammer, K.; VAn DE ViJVer, B.; Tuji, A.; Simkhada, B.; Gurung, S.; Sharma, S.; Sharma, C. \& Cox, E.J. (2010a): Oricymba (Cymbellales, Bacillariophyceae), a new cymbelloid genus and three new species from the Nepalese Himalaya. - Phycologia 49: 407-423.

Jüttner, I.; Gurung, S.; Sharma, C; Sharma, S.; De HaAn M. \& VAN DE VIJVER, B. (2010b): Morphology of new taxa in the Cymbella aspera and Cymbella neocistula groups, Cymbella yakii sp. nov. and Cymbella $\mathrm{cf}$. hantzschiana from Everest National Park, Nepal. Polish Botanical Journal 55: 73-92.

Kasputin, D.A.; KulikovskiY, M. \& Kociolek, J.P. (2017): Celebesia gen. nov., a new Cymbelloid diatom genus from the ancient lake Matano (Sulawesi Island, Indonesia). - Nova Hedwigia 146: 147-155.

Krammer, K. (1997a): Die Cymbelloiden Diatomeen. Eine monography der weltweit bekannten Teil 1. Allgemeines und Encyonema Part. - Bibliotheca Diatomologica 36: $1-382$.

Krammer, K. (1997b): Die Cymbelloiden Diatomeen. Eine monography der weltweit bekannten Teil 2. Encyonema Part, Encyonopsis und Cymbellopsis. - Bibliotheca Diatomologica 37: 1-470.

Krammer, K. (2002): Cymbella - Diatoms of Europe 3: 1-584.

Krammer, K. (2003): Cymbopleura, Delicata, Navicymbella, Gomphocymbellopsis, Afrocymbella. - Diatoms of Europe 4: 1-529.

Kulikovskiy, M.; Lange-Bertalot, H.; Metzeltin, D. \& WiTKOwsKi, A. (2012): Lake Baïkal: hotspot of endemic species diatoms 1. - Iconography Diatomologica 23: 7-607.

Kulikovskiy, M. \& Kuznetsova, I.V. (2016): Morphology, taxonomical position and distribution of the genera Ochigma and Khursevichia from lake Baïkal. - Inland water Biology 9: 226-233.

LANGE-BERTALOT, H. (2001): Navicula sensu stricto, 16 genera separated from Navicula sensu lato, Frustulia. - Diatoms of Europe 2: 1-526.
Lange-Bertalot, H.; Cavacini, P.; Tagliaventi, N. \& Alfinito, S. (2003): Diatom of Sardinia. - Iconographia Diatomologica 12: 1- 438.

Lange-Bertalot, H.; Fumanti, B.; Cavacini, P. \& Tagliaventi, N. (2009): The genus Navigiolum (Bacillariophyceae) in Mediterranean and North African rock pool habitas: description of four new species from Algeria. - Fottea 9: 179-185.

Le CoHU, R. (1983): Observations sur deux espèces de diatomées du genre Diatomella: Diatomella hustedtii MANGuIN et Diatomella ouenkoana MAILlarD. - Cryptogamie, Algologie 4: 63-71.

LE CoHu, R. (1985): Ultrastructure des diatomées de NouvelleCalédonie. Première partie. - Annales de Limnologie 21: 3-12.

Le Cohu, R. \& AzÉmar, F. (2011): Etude morphologique de quelques Cymbellaceae des Pyrénées françaises incluant la description d'une nouvelle espèce: Delicata couseransis sp. nov. - Cryptogamie Algologie 32: 131-155.

Le Cohu, R.; Marquie, J. \& Tudesque, L. (2018): Three new species of Delicata (Bacillariophyceae - Cymbellales) from New Caledonia and further observations on Delicata nepouiana Krammer and D. neocaledonica Krammer. - Diatom Research 33: 39-53.

Le Cohu, R.; Marquie, J. \& Tudesque, L. (2019): Three new species of Delicatophycus M.J. Wynne (Gomphonemataceae, Bacillariophyta) from new Caledonia. - Notulae algarum 86: 1-2.

LiU, B.; Blanco, S. \& Lan Q-Y. (2018): Ultrastructure of Delicata sinensis Krammer \& Metzeltin and D. williamsii sp. nov. (Bacillariophyta) from China. - Fottea 18: $30-36$.

MaIllard, R. (1978): Contribution à la connaissance des diatomées d'eau douce de la Nouvelle-Calédonie. - Cahiers de l'ORSTOM, Série Hydrobiologie 12: 143-172.

Majewska, R.; Bosak S.; Frankovich, T.A.; Ashworth, M.P.; SUlliVAn, M.J.; ROBINSON, N.J.; LAZO-WASEM, E.A.; Pinou, T.; Nel. R.; Manning, S.R. and Van DE ViJver, B. (2019): Six new epibiotic Proschkinia (Bacillariophyta) species and new insights into the genus phylogeny. - European Journal of Phycology (published online 27/08/2019) https://doi.org/10.108 0/09670262.2019.1628307

MAnguin, E. (1962): Contribution à la connaissance de la flore diatomique de la Nouvelle-Calédonie. - Mémoires du Muséum National d'Histoire Naturelles, série b, Botanique 12: 1-40.

Marquie, J.; Le Cohu, R. \& Coste, M. (2018) : Adlafia moseri and $A$. tjibaoui two new diatom species (Bacillariophyta) from New Caledonia with further observations on Adlafia muscora and Kobayasiella saxicola. - Phytotaxa 357: 41-51.

Morat, P.; Jaffré, T.; Tronchet, F.; Munzinger, J.; Pillon, Y.; Veillon, J.-M.; Chapolin, M.; Birnbaum, P.; Rigault, F.; Dagostini, G.; Tinel, J. \& Lowry, P.P. (2012): Le référentiel taxonomique Florical et les caractéristiques de la flore vasculaire indigène de la Nouvelle-Calédonie. - Adansonia 34: 179-221.

Moser, G. (1999) : Die diatomeenflora von Neukaledonien. - Bibliotheca Diatomologica 43: 1-205.

Moser, G.; Steindorf, A. \& Lange-Bertalot, H. (1995): Neukaledonien - Diatomeenflora einer Tropeninsel Revision der Collection MaILlaRD und Untersuchung neuen Materials. - Bibliotheca Diatomologica 32: 1-340. 
Moser, G.; Lange-Bertalot, H.; \& Metzeltin, D. (1998): Insel der Endemiten. Geobotanisches Phänomen Neukaledonien. - Bibliotheca Diatomologica 38: 1-464.

PAtrick, R. \& Reimer, C.W. (1966): The diatoms of the United States exclusive of Alaska and Hawaii. Volume 1: Fragilariaceae, Eunotiaceae, Achnanthaceae, Naviculaceae. - Monographs of the Academy of Natural Sciences of Philadelphia 13: 1-688.

Rodionovia, Y.V.; Pomazkina, G.V. \& Makarevich, O.Y. (2013): Encyonema mirabilis, Cymbella olgae and C. cognata: New diatom species from Lake Baikal. Diatom Research 28: 487-502.

Ross, R.; Cox, E.J.; Karayeva, N.I.; Mann, D.G.; Paddock, T.B.B.; SimONSEN, R. \& Sims, P.A. (1979): An amended terminology for the siliceous components of the diatom cell - Nova Hedwigia 64: 513-533.

Round, F.E.; Crawford, R.M. \& MAnN, D.G. (1990): The diatoms. Biology and morphology of the Genera. -747 pp., Cambridge University Press, Cambridge.

Sabbe, K.; Vyverman, W.; Ector, L.; Wetzel, C.E.; John, J.; Hodgson, D.A.; Verleyen, E. \& VAN DE ViJVer, B. (2019): On the identity of Navicula gottlandica (Bacillariophyta), with the description of two new species Navicula eileencoxiana and Navicula bergstromiana from the Australo-Pacific region. - Plant Ecology and Evolution 152: 313-326.

SimONSEN, R. (1974): The diatom plankton of the Indian
Ocean Expedition of R/V Meteor 1964-5. - Meteor Forschungsergebnisse. Reihe D: Biologie 19: 1-107. Stancheva, R. \& Ivanov, P. (2011): Cymbella orientalis var. delicatula sp. nov. (Bacillariophyta), a new epilithic stream diatom from Bulgaria. - Nova Hedwigia 93: 453-464.

VAn De Vijver, B. \& LANGe-Bertalot, H. (2008): Cymbella amelieana sp. nov, a new large Cymbella species from Swedish rivers. - Diatom Research 23: 511-518.

Van De Vijver, B. \& Le Cohu, R. (2017): Diatomella colonialis, a new diatom species (Bacillariophyta) from the sub-Antarctic Region. - Phytotaxa 306: 281-286.

VAn De Vijver, B. \& Le CoHu, R. (2019): Validation of "Cocconeis therezienii Le CoHU \& MAILLARD", a freshwater diatom species (Cocconeidaceae, Bacillariophyta) from the subantarctic îles Kerguelen. Notulae algarum 86: 1-3.

Watanabe, T. \& AsaI, K. (2008): Diatom assemblage occurring in streams and springs near Numea, the capital of New Caledonia. - Diatom 24: 63-72.

Wynne, M.J. (2019): Delicatophycus gen. nov: a validation of "Delicata" Krammer inval. (Gomphonematacea, Bacillariophyta). - Notulae algarum 97: 1-2.

(C) Czech Phycological Society (2020)

Received October 11, 2019

Accepted November 12, 2019 